\title{
Effect of Siddha Samadhi Yoga Camps on Health and Nutritional Status of Normal and Diabetic Subjects
}

\section{Sreedevi $\mathrm{K}^{1 *}$, Devaki $\mathrm{PB}^{2}$ and Bhushanam $\mathrm{GV}^{3}$}

${ }^{1}$ Nutrition Consultant, Behavioral Science Unit, National Institute of Nutrition, Hyderabad, India

${ }^{2}$ Faculty of Food Science \& Nutrition, Sri Venkateshwara University, Tirupathi, India

${ }^{3}$ All India Coordinated Research Project on Home Science, Acharya NG Ranga Agricultural University, Hyderabad, India

\begin{abstract}
Introduction: Now-a-days a new way of life comprising of yogasana, pranayama, meditation and changed food habits is expected to lead a happy purposeful life with heightened consciousness and perceptiveness. One such yoga camp is Siddha Samadhi Yoga (SSY) camp which is believed to invoke the intellectual, emotional, mental and physical potential in each individual. These yoga camps claim to have the powers of reversing the ill effects of degenerative diseases. In view of the beneficial effects of Yoga, Meditation and changed food habits the effect of Siddha Samadhi Yoga (SSY) camp's on normal and diabetic subjects was planned.
\end{abstract}

Materials \& methods: Thirty normal and thirty diabetic male subjects free from additional complications belonging to twenty five to forty five years of age were selected from two camps conducted in Mahaboob Nagar and Tirupathi. The BMI of all subjects was assessed. Blood samples were analysed for post prandial blood glucose; serum cholesterol; serum iron and haemoglobin levels. Diet Survey was conducted on the basis of food intake record provided by the subjects. The food habits of normal and diabetic subjects before and after the SSY camp of 18 days was also studied.

Results \& discussion: There was a significant difference in pre and post prandial blood glucose level of Normal subjects $(t=4.9811>2.05)$ and Diabetics $(t=24.4962>2.05)$. The percent reduction in $\mathrm{BMI}$ is 4.2 and 4.1 in normal and diabetic subjects respectively. Serum cholesterol levels among diabetics reduced by $4.1 \%$ and by $2.99 \%$ in normal subjects. Serum Iron and haemoglobin levels improved in normal subjects by $8.4 \%$ and $14.95 \%$ respectively in normal subjects while by $5 \%$ and $6.9 \%$ respectively in diabetics.

Summary \& conclusion: The SSY camp has a significant effect in decreasing the post-prandial blood glucose and serum cholesterol levels, intake of calories, carbohydrates, cholesterol, fat and significant increase in the intake of fibre, vitamin C, iron and B-carotene.

\section{Introduction}

Degenerative diseases and cancer are emerging as major causes of death not only in India but in other South and Southeast Asian countries as well. If present trends continue, India could emerge as one of the countries with the highest concentration of cases of diabetes mellitus and Coronary Heart Disease (CHD) within the next three decades [1].

Yogic exercises are getting popular all over the world, not only for health and physical fitness, but also for therapeutic purposes. Yogic training tends to reduce the cholesterol level which is significant in individuals having above normal limits [2]. Meditation reduces bodily stress which is evident with reduced blood levels of cortisol and a lowered rate of urinary excretion of nitrogen and may prove useful for persons suffering from anxiety state and depression [3].

Antioxidant deficiency and free radical stress may be a risk factor for the development of diabetes and cardiovascular disease. It is possible that treatment with antioxidant vitamins may be protective [4]. Now-a-days a new way of life comprising of yogasana, pranayama, meditation and changed food habits which is expected to lead a happy purposeful life with heightened consciousness and perceptiveness. One such yoga camp is Siddha Samadhi Yoga (SSY) camp which is said to invoke the true intellectual, emotional, mental and physical potential in each individual. These yoga camps claim to have the powers of reversing the ill effects of degenerative diseases [5].

In view of the beneficial effects of Yoga, Meditation and changed food habits the effect of Siddha Samadhi Yoga (SSY) camp's on normal and diabetic subjects was planned.

\section{Materials \& Methods}

Thirty normal and thirty diabetic male free from further complications of twenty five to forty five years of age were selected from two camps conducted in Mahaboob Nagar and Tirupathi, Andhra Pradesh, India. General information regarding economic status, educational status, occupation, family size etc. was elicited using General information questionnaire.

The BMI of all subjects were calculated based on the heights and weights recorded. Blood samples were analysed for post prandial blood glucose; serum cholesterol; serum iron and haemoglobin levels. Diet Survey was conducted on the basis of food intake record provided by the subjects before and at the end of the SSY camp of 18 days.

The height and weight of all subjects were recorded following the methods of Jellifee [6] BMI was calculated using the formula weight in

*Corresponding author: Sreedevi K, Nutrition Consultant, Behavioral Science Unit, National Institute of Nutrition, Hyderabad, India, Tel: 9492059106; E-mail: kareddy_sree@yahoo.co.in

Received April 09, 2012; Accepted May 28, 2012; Published June 04, 2012

Citation: Sreedevi K, Devaki PB, Bhushanam GV (2012) Effect of Siddha Samadh Yoga Camps on Health and Nutritional Status of Normal and Diabetic Subjects. Diabetes Metab 3:195. doi:10.4172/2155-6156.1000195

Copyright: @ 2012 Sreedevi K. This is an open-access article distributed unde the terms of the Creative Commons Attribution License, which permits unrestricted use, distribution, and reproduction in any medium, provided the original author and source are credited. 
Citation: Sreedevi K, Devaki PB, Bhushanam GV (2012) Effect of Siddha Samadhi Yoga Camps on Health and Nutritional Status of Normal and Diabetic Subjects. J Diabetes Metab 3:195. doi:10.4172/2155-6156.1000195

Page 2 of 3

$\mathrm{kg} /$ height in $\left(\mathrm{m}^{2}\right)$ and compared with standard classification of James et al. (1998). Five $\mathrm{ml}$ of the blood was drawn from each subject and divided into three portions, one for estimation of blood glucose by Nelson and Somayagi [7] method, second for the estimation of serum cholesterol by Carr and Drekter [8] Method and the other for serum iron by $\Leftarrow \Leftarrow$ dipyridyl method [9], and finger prick samples were collected to estimate haemoglobin levels by cyanomethaemoglobin method [10].

WHO expert consultation recommends the acceptability of glycated haemoglobin, or HbA1c, as an additional test to diagnose diabetes. The higher cost in comparison to other diagnostic tools will, for now, will make it harder for developing countries to use. It also remains unreliable in medical conditions with rapid red cell turnover, such as haemolytic or iron deficiency anaemias. So the priority for low-income countries will continue to be ensuring the availability of blood glucose measurement at the primary health care level before widely introducing $\mathrm{HbA1c}$ for diagnosing diabetes [11]. Cost has become a major influencing factor in using Nelson Somyogi method as against HbA1c method.

Moreover, HbAlc results can be misleading when red blood cell survival is prolonged or reduced; some health conditions can result in falsely high A1c results (as in cases of anemia) or falsely low (as in cases of hemolysis) and only subjects with a substantially reduced glucose tolerance may be diagnosed by HbA1c determinations [12].

Diet survey was conducted to note down the food items consumed over a period of three days ( 2 working days +1 holiday) before and at the end of the SSY camp using standard cup to measure the food they consumed. Based on the food intake record food consumed per day was computed. The mean nutrients were calculated by using the tables of food values.

The data on BMI, blood glucose; serum cholesterol; serum iron and haemoglobin levels, Dietary pattern and intake and personal well being of normal and diabetic subjects was analyzed statistically. The percentages, mean, standard deviation, $\mathrm{t}$ - value and their test of significance were calculated.

\section{Results \& Discussion}

The results on the effect of yoga camp on health status of normal and diabetic subjects with reference pre and post levels of blood glucose and serum cholesterol is presented in Table 1.

The mean difference between the pre and post blood glucose level of Normal and NIDDM subjects was $2.38 \mathrm{mg} / \mathrm{dl}$ and $35.38 \mathrm{mg} / \mathrm{dl} \mathrm{re-}$

\begin{tabular}{|c|c|c|c|c|c|c|c|}
\hline \multirow{2}{*}{$\begin{array}{l}\text { Details } \\
\text { of } \\
\text { sub- } \\
\text { jects }\end{array}$} & \multirow{2}{*}{$\begin{array}{l}\text { Lev- } \\
\text { els }\end{array}$} & \multicolumn{3}{|c|}{ Blood Glucose } & \multicolumn{3}{|c|}{ Serum Cholesterol } \\
\hline & & Mean \pm SD & $\begin{array}{l}\text { Difference } \\
\text { in pre \& } \\
\text { post mean } \\
\pm \text { SD }\end{array}$ & \begin{tabular}{|l|} 
t' \\
val- \\
ue
\end{tabular} & Mean \pm SD & $\begin{array}{l}\text { Differ- } \\
\text { ence } \\
\text { in pre } \\
\& \text { post } \\
\text { mean } \pm \\
\text { SD }\end{array}$ & $\begin{array}{l}\text { t' } \\
\text { val- } \\
\text { ue }\end{array}$ \\
\hline \multirow{2}{*}{$\begin{array}{l}\text { Normal } \\
\text { Sub- } \\
\text { jects } \\
(n=30)\end{array}$} & $\begin{array}{l}\text { Pre- } \\
\text { level }\end{array}$ & $147.46 \pm 10.43$ & \multirow{2}{*}{$2.38 \pm 2.32$} & \multirow[t]{2}{*}{4.87} & $236.42 \pm 7.13$ & \multirow[t]{2}{*}{$6.86 \pm 5.26$} & \multirow[t]{2}{*}{7.14} \\
\hline & $\begin{array}{l}\text { Post- } \\
\text { level }\end{array}$ & $145.08 \pm 10.16$ & & & $229.56 \pm 5.3$ & & \\
\hline \multirow{3}{*}{$\begin{array}{l}\text { NIDDM } \\
\text { Sub- } \\
\text { jects } \\
(n=30)\end{array}$} & $\begin{array}{l}\text { Pre- } \\
\text { level }\end{array}$ & $233.43 \pm 19.84$ & \multirow{3}{*}{$35.38 \pm 7.91$} & \multirow{3}{*}{24.49} & $225.83 \pm 4.56$ & \multirow{3}{*}{$9.13 \pm 3.25$} & \multirow{3}{*}{15.48} \\
\hline & $\begin{array}{l}\text { Post- } \\
\text { level }\end{array}$ & $198.05 \pm 6.2$ & & & $216.64 \pm 6.18$ & & \\
\hline & $\begin{array}{l}\text { Post- } \\
\text { level }\end{array}$ & $145.4 \pm 5.44$ & & & $250.05 \pm 7.82$ & & \\
\hline
\end{tabular}

Table 1: Pre and post levels of blood glucose and cholesterol levels.

\begin{tabular}{|c|c|c|c|c|}
\hline \multirow{2}{*}{$\begin{array}{l}\text { Details of Sub- } \\
\text { jects }\end{array}$} & \multirow[t]{2}{*}{ Levels } & \multicolumn{3}{|c|}{ Serum Levels } \\
\hline & & Mean \pm SD & $\begin{array}{l}\text { Difference in pre } \\
\& \text { post mean } \\
+ \text { SD }\end{array}$ & t'value \\
\hline \multirow{2}{*}{$\begin{array}{l}\text { Normal Subjects } \\
(n=30)\end{array}$} & Pre-Levels & $143.68 \pm 11.83$ & \multirow[t]{2}{*}{$12.01 \pm 5.1$} & \multirow[t]{2}{*}{12.88} \\
\hline & Post-Levels & $155.69 \pm 9.96$ & & \\
\hline \multirow{2}{*}{$\begin{array}{l}\text { NIDDM Subjects } \\
(n=30)\end{array}$} & Pre-Levels & $138.79 \pm 8.9$ & \multirow[t]{2}{*}{$6.94 \pm 3.43$} & \multirow[t]{2}{*}{11.06} \\
\hline & Post-Levels & $145.73 \pm 8.17$ & & \\
\hline
\end{tabular}

Table 2: Serum iron levels before and after SSY camp.

\begin{tabular}{|c|c|c|c|c|}
\hline \multirow{2}{*}{$\begin{array}{l}\text { Details of } \\
\text { Subjects }\end{array}$} & \multirow[t]{2}{*}{ Levels } & \multicolumn{3}{|c|}{ Blood Haemoglobin Levels } \\
\hline & & Mean \pm SD & $\begin{array}{l}\text { Difference in } \\
\text { pre \& post } \\
\text { mean + SD }\end{array}$ & t' value \\
\hline \multirow{2}{*}{$\begin{array}{l}\text { Normal } \\
\text { Subjects }(n=30)\end{array}$} & Pre-Levels & $10.72 \pm 1.35$ & \multirow[t]{2}{*}{$1.32 \pm 0.77$} & \multirow[t]{2}{*}{9.1} \\
\hline & Post-Levels & $12.03 \pm 1.0$ & & \\
\hline \multirow{2}{*}{$\begin{array}{l}\text { NIDDM Sub- } \\
\text { jects }(n=30)\end{array}$} & Pre-Levels & $10.23 \pm 0.98$ & \multirow[t]{2}{*}{$0.77 \pm 0.61$} & \multirow[t]{2}{*}{6.69} \\
\hline & Post-Levels & $10.99 \pm 0.97$ & & \\
\hline
\end{tabular}

Table 3: Blood Haemoglobin levels of male subjects before and after SSY camp.

spectively. The percent reduction of blood glucose was $1.6 \pm 7.9$ in Normal and $15.15 \pm 7.9$ in Diabetic subjects.

Statistically there is a significant difference in pre and post prandial blood glucose level of Normal subjects $(t=4.9811>2.05)$ and Diabetics $(t=24.4962>2.05)$. The ' $t$ ' value is greater than ' $t$ ' critical value at 5 percent level. The percent reduction of serum cholesterol level in Group I was $2.901 \pm 5.26$ and $4.069 \pm 3.249$ in group II.

Generally among normal subjects before breakfast blood usually contains about $80 \mathrm{mg} / \mathrm{dl}$ glucose. After a meal the concentration rises because, the glucose absorbed from the gut passes through the liver in to general circulation, it may reach $132 \mathrm{mg}$ or even more, but rarely exceeds $177 \mathrm{mg}$ at which point glucose usually into the urine and in diabetics the mean fasting blood glucose level is very high, $120 \mathrm{mg} / \mathrm{dl}$ and the post prandial level is higher $180 \mathrm{mg} / \mathrm{dl}$. It is observed that half of the subjects have above the normal range of post-prandial blood glucose level and in NIDDM subjects were having above the limits.

The effect of yoga camp of normal and diabetic subjects on the pre and post serum iron is presented in Table 2.

The difference in pre and post serum iron levels was $12.01 \mathrm{ug} / \mathrm{dl}$ in group I and $145.73 \mathrm{ug} / \mathrm{dl}$ in group II. There was percent decrease in serum iron levels $(8.35 \pm 5.1)$ in group I against a percent increase of $5.0 \pm 3.43$ in group II.

There is a significant between pre and post serum iron levels of Group I and group II. The increase in the serum iron levels from pre to post level in Normal subjects was statistically highly significant $(\mathrm{P}<$ $0.05)$ compared to NIDDM subjects.

Though a controlled design is more robust when compared to a pre (intervention) and post (intervention) design this study used the later as it was undertaken with very limited resources and could not consider inclusion of a control group, this as a limitation of the study.

The mean blood haemoglobin levels of normal and diabetic subjects were 10.7 and $10.2 \mathrm{~g} / \mathrm{dl}$ respectively. The post levels were 12.03 and $10.9 \mathrm{~g} / \mathrm{dl}$ respectively. Healthy normal adult man has about $13-14$ $\mathrm{g} \%$ blood haemoglobin [11]. The difference between pre and post level among normal subjects was $1.32 \mathrm{~g}$ and percent increase in haemoglobin was $12.27 \pm 0.77$ and the difference between pre and post level was 0.77 $g$ and percent increase in haemoglobin was $7.55 \pm 0.61$ among NIDDM subjects. 
Citation: Sreedevi K, Devaki PB, Bhushanam GV (2012) Effect of Siddha Samadhi Yoga Camps on Health and Nutritional Status of Normal and Diabetic Subjects. J Diabetes Metab 3:195. doi:10.4172/2155-6156.1000195

Page 3 of 3

\begin{tabular}{|c|c|c|c|c|c|c|c|c|c|}
\hline \multirow[t]{2}{*}{ Details of Subjects } & \multirow[t]{2}{*}{ Levels } & \multicolumn{8}{|c|}{ Nutrients } \\
\hline & & Energy & Carbohy-drate & Protein & Fat & Fibre & Iron & B- Carotene & Vitamin C \\
\hline \multirow{2}{*}{$\begin{array}{l}\text { Normal Subjects } \\
\quad(n=30)\end{array}$} & Before SSY & 1786.63 & 213.43 & 49.92 & 54.58 & 1.76 & 19.82 & 1784.12 & 31.1 \\
\hline & During SSY & 1640.08 & 190.48 & 48.97 & 39.32 & 2.43 & 26.06 & 2091.93 & 36.91 \\
\hline \multirow{2}{*}{$\begin{array}{l}\text { NIDDM Subjects } \\
\qquad(n=30)\end{array}$} & Before SSY & 1786.63 & 247.76 & 53.45 & 50.03 & 1.69 & 19.89 & 1735 & 28.3 \\
\hline & During SSY & 1576.84 & 193.89 & 50.6 & 53.38 & 3.52 & 25.2 & 2002.2 & 39.7 \\
\hline
\end{tabular}

Table 4 : Nutrient intake of Subjects before and during SSY program.

In diabetics as the concentration of glucose in blood rises, more of it gets attached to haemoglobin and the combined molecule chemically estimated as glycosylated haemoglobin. In normal population the glycosylated haemoglobin concentration varies from 4 to $7 \%$, while in diabetics it ranges from 8 to $18 \%$ of the total haemoglobin depending on the blood sugar level.

The effect of yoga camp of normal and diabetic subjects on the pre and post levels of dietary pattern is presented in Table 3.

4.638 percent reduction of calories was observed in Group I and 11.74 in group II. Percent reduction in carbohydrate; Protein; Fat dietary cholesterol was observed in group I \& II. Percent increase in intake of Fibre and Iron was observed in group I and II. The percent intake of carotene was 14.71 in group I and 13.4 in group II but these values are still lower than the standard recommended intake which may be due to lowered intake of diet. In the present study a low degree of positive correlation was found between Vitamin $\mathrm{C}$ and post prandial blood glucose levels in Normal and diabetic subjects. There is a highly significant correlation between Vitamin $\mathrm{C}$ and post prandial blood glucose in normal subjects $(r=0.484)$. From this it is evident that if Vitamin $\mathrm{C}$ intake is increased, post prandial blood glucose is controlled.

\section{Summary \& Conclusion}

The SSY camp has a significant effect in decreasing the post-prandial blood glucose and serum cholesterol levels, intake of calories, carbohydrates, cholesterol, fat and significant increase in the intake of fibre, vitamin $\mathrm{C}$, iron and B-carotene. The correlations obtained between the health parameters, haematological parameters and the energy and nutrient intakes are very obvious and significant. Therefore efforts should be made to practice the food habits, regular exercise, yoga and meditation for continued beneficial effect.

\section{References}

1. Gopalan C (1996) Diet related chronic diseases in India changing trends Bulletin of the Nutrition Foundation of India 17: 1-5.

2. Udupa KN, Singh RH, Settiwar RM (1975) A comparative study on the effect of some individual yogic practices in normal persons. Indian J Med Res 63 1066-1071.

3. Udupa KN, Singh RH (1978) Physiological studies on the effort of a Yogic relaxation posture Savasana. J Res Ind Med Yoga \& Homoeo 13: 147.

4. Maritim AC, Sanders RA, Watkins JB 3rd (2003) Diabetes, Oxidative stress and antioxidants: A Review. J Biochem Mol Toxicol 17: 24-38.

5. Yogeswar (1981) Textbook of Yoga, Madras

6. Jellifee (1996) Assessment of Nutritional Status of the Community: with special reference to field surveys in the developing regions of the world, WHO Geneva.

7. Nelson N, Somayagi M (1965) Determination of Glucose, Hawk's Physiologica Chemistry, Osler B2 Ed., New York, Mc Graw Hill Book Company, (14thEdn): 1054-1055.

8. Carr JJ, Drekter IJ (1956) Simplified Rapid Technic for the Extraction and Determination of Serum Cholesterol without Saponification. Clin Chem 2: 353-368.

9. Ramsay WN (1973) The measurement of serum transferrin by iron binding capacity. J Clin Pathol 26: 691-696.

10. Crosby WH, Munn JI, Furth FW (1954) Standardizing a method for clinical hemoglobinometry. U S Armed Forces Med J 5: 693-703.

11. WHO (2011) Use of Glycated Haemoglobin (HbA1c) in the Diagnosis of Diabetes Mellitus: Abbreviated Report of a WHO Consultation.

12. WHO (1975) WHO, Nutritional anaemia, W.H.O. Tech Rep Series 503 